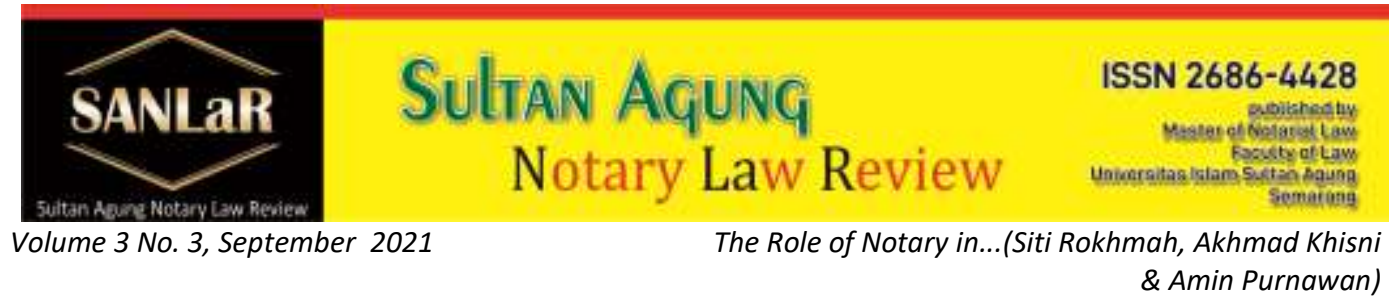

\title{
The Role of Notary in Making the Deed of Power of Attorney Imposing Mortgage on Land Collateral
}

\author{
Siti Rokhmah*), Akhmad Khisni ${ }^{* *}$, and Amin Purnawan $\left.{ }^{* * *}\right)$ \\ ${ }^{*}$ Faculty of Law, Universitas Islam Sultan Agung (UNISSULA) Semarang, E-mail: \\ sitirokhmah2121@gmail.com
}
${ }^{* *}$ Faculty of Law, Universitas Islam Sultan Agung (UNISSULA) Semarang, E-mail: khisni@unissula.ac.id

$\left.{ }^{* * *}\right)$ Faculty of Law, Universitas Islam Sultan Agung (UNISSULA) Semarang, E-mail: amin.p@unissula.ac.id

\begin{abstract}
The purpose of this study was to identify and analyze the role of the Notary in making the Deed of Power of Attorney for Imposing Mortgage Rights (SKMHT) on uncertified land collateral at Bank BPR Karya Remaja Indramayu Regency, along with obstacles and solutions. This study uses an empirical juridical approach and the specifications of this study use a descriptive analytical method with a qualitative approach. The sources and types of data in this study are primary data obtained from field studies with interviews. And secondary data obtained from literature studies related to the theory of legal certainty and authority. Based on the results of the study, it was concluded that in practice the Notary made SKMHT in accordance with Article 15 UUHT to bind collateral for uncertified land to be used as collateral, and had fulfilled what was stipulated in Article 38 of the UUJN regarding the beginning of the Deed, the body of the Deed, and the closing. Deed. The obstacles faced by Notaries are a). The inhibiting factor from the Bank, namely the incomplete document, b). The Inhibiting Factor from the Debtor is the problem of the amount of fees. c). Bad credit. The solutions to overcome these obstacles are: a). Give 7 working days to complete documents from the Bank or customer. b). Negotiated costs with a Notary, c). Banks are careful in providing credit.
\end{abstract}

Keywords: Notary; Mortgage; Right; SKMHT; Collateral; Land.

\section{Introduction}

The presence of a notary is increasingly important for the Indonesian people today whose economy continues to grow. The public uses the services of a 
notary to provide legal certainty in the field of engagements and agreements. An undeniable fact is that along with economic growth with the proliferation of banking to remote areas, a notary is needed as an official who makes authentic deeds. This means that the role of a notary for the state, its existence is a must and is needed to assist the state in the field of private law and state administration, especially with regard to legal certainty in the field of engagements and agreements. The complexity of the work and problems, as well as the risks faced require legal certainty from the presence of an authentic deed made by a notary. ${ }^{1}$

Notaries in carrying out their duties are based on laws and regulations which currently refer to the Notary Position Act Number 2 of 2014. This means that a Notary is a position given to someone who has the main authority to make an authentic deed at the request of the parties. The term "public official" can be interpreted as an official who is appointed by the government and has certain authority in a permanent work environment related to service to the community. The authority of a Notary as a public official is limited to what is given by the law governing the position of a Notary. ${ }^{2}$

Deed is a signed letter, containing information about the events that are the basis of an agreement. Article 1867 of the Civil Code states: "Written proof is carried out in authentic writing or in writing under the hand." Based on the above provisions, there are two kinds of deeds, namely authentic deeds and private deeds. ${ }^{3}$ The deed made by a notary has an important role in creating legal certainty in every legal relationship, because the notarial deed is authentic, and is the strongest evidence in every case related to the notary deed. The strength of a notary deed as evidence lies in the peculiarity of the character of the maker, namely the notary as a public official who is specifically authorized to make a deed. ${ }^{4}$

The development that is being actively carried out by the Government is essentially one of the efforts to improve the people's standard of living. One way to improve the standard of living is to develop the economy and trade through the role of banks in lending. In supporting their business, entrepreneurs, both small, medium and large entrepreneurs and even individuals need additional

\footnotetext{
${ }^{1}$ Handoko, Widhi. (2019). Dominasi Negara Terhadap Profesi Notaris Antara Ide dan Realitas. Bogor: Roda Publikasi Kreasi. p. 36.

${ }^{2}$ Adjie, Habib. (2019). Hukum Notaris Indonesia (Tafsir Tematik Tehadap UU No.30 Tahun 2004 tentang Jabatan Notaris). Bandung: Refika Aditama. p. 16.

${ }^{3}$ Dimas Agung Prastomo, Akhmad Khisni,. (2017). “Akibat Hukum Akta Di Bawah Tangan Yang Dilegalisasi Oleh Notaris". In Jurnal Akta, vol. 4, No.4 December, 2017. p. 728. Url. http://jurnal.unissula.ac.id/index.php/akta/article/view/2519. accessed on 3 March 2021.

${ }^{4}$ Sjaifurrachman. (2011). Aspek Pertanggungjawaban Notaris dalam Pembuatan Akta. Bandung: Mandar Maju. p. 7.
} 
funds. One of the additional funds is done by applying for a credit loan at the bank. The provisions in the Banking Law state that "credit is the provision of money or equivalent claims, based on an agreement or loan agreement between a bank and another party that requires the borrower to repay his debt after a certain period of time with interest". ${ }^{5}$

Since the enactment of Act No. 4 of 1996 concerning Mortgage Rights on Land and Objects Related to Land, a mortgage object that is used as collateral in the form of land, hereinafter referred to as Mortgage Rights (HT) is a security right that is imposed on land rights, which are one unit with the land for the settlement of certain debts, which gives priority to certain creditors over other creditors. This means that Mortgage is a form of guarantee for debt repayment. ${ }^{6}$

SKMHT is an abbreviation of Power of Attorney for Imposing Mortgage Rights. This power of attorney is given by the mortgagee to the creditor as the recipient of the mortgage to impose the mortgage on the object of the mortgage. This SKMHT is a special power of attorney that gives special powers to creditors to impose mortgage rights. This letter must be made with a notarial deed or PPAT deed. $^{7}$

Based on the above background, the author wants to examine the importance of the role of a notary in making SKMHT in Indramayu Regency, especially at Bank BPR Karya Remaja Indramayu which provides services in the banking sector in order to support the economy of the Indramayu community. This study aims to determine and analyze the role of the Notary in making the Deed of Power of Attorney for Imposing Mortgage on uncertified land collateral at Bank BPR Karya Remaja, Indramayu Regency, as well as to identify and analyze obstacles and solutions.

\section{Research Methods}

This study uses an empirical juridical approach, namely research that focuses on individual behavior or behavior society in relation to the law. Juridical research is carried out by examining library materials which are secondary data and also called library research. Empirical research is carried out by researching the field

\footnotetext{
${ }^{5}$ The provisions of Article 1 paragraph (11) of Act No. 10 of 1998 concerning Amendments to Act No. 7 of 1992 concerning Banking.

${ }^{6}$ Supramono, Gatot. (2013). Perjanjian Utang Piutang. Jakarta: Kencana. p. 117.

${ }^{7}$ Sayuna, Inche. (2014). "Problematika Surat Kuasa Membebankan Hak Tanggungan (SKMHT) Dari Dimensi: Subjek, Objek dan Kepentingan Yuridis". In Jurnal Reportorium Volume 1, Nomor 1, January-June 2014, p. 50. Url. https://www.neliti.com/publications/212960/problematika-suratkuasa-membebankan-hak-tanggungan-skmht-dari-dimensi-subjek-ob. Accessed on 15 March 2021.
} 
which is primary data. ${ }^{8}$ This research is using descriptive analytical method with a qualitative approach. The use of this approach is adapted to the main objective of the study, namely to identify and analyze the role of a notary in making the SKMHT deed againstland collateral that has not been certified at the BPR Karya Remaja bank, Indramayu Regency.

\section{Results and Discussion}

\subsection{Implementation of Making SKMHT}

The implementation of making a Power of Attorney for Imposing Mortgage Rights (SKMHT) by a Notary at Bank BPR Karya Remaja, Indramayu Regency is after the credit agreement. SKMHT as a form of guarantee for repayment of debt from the debtor to the creditor as the financier.

a. Stage Before the Credit Agreement.

Power of Attorney for Imposing Mortgage (SKMHT) is a power of attorney granted by the Mortgage provider to the creditor as the Mortgage recipient to impose Mortgage on the Mortgage object. In practice the SKMHT Notary is used in accordance with Article 15 paragraph (4) of the Mortgage Law (UUHT), to bind collateral for uncertified land that will be used as collateral/collateral.

Before making a credit agreement, the repayment of which is guaranteed by using SKMHT, the parties first make an agreement about what will be made and specified in the agreement. The substance of making this SKMHT is limited, namely only containing legal actions to impose mortgage rights.

b. Credit Agreement Signing Stage.

The making of SKMHT by a Notary is carried out after or simultaneously when the credit agreement will be signed by the creditor and debtor, the content of the SKMHT is the control of the debtor to the creditor to be upgraded to APHT. As for several things that cause the use of SKMHT is that the object of land used as collateral for loans/credits has not been registered at the local Land Office.

After the SKMHT deed is read by the Notary, then the deed is signed which shows that the SKMHT made was indeed agreed upon by the parties. The inclusion of the date, day, month and year in making SKMHT shows that there is a time limit for the parties, especially creditors as capital givers or proxies to

${ }^{8}$ Syamsudin, M. (2007). Operasionalisasi Penelitian Hukum, Jakarta: PT Raja Grafindo Persada. p. 1. 
pay attention to the time period regarding the validity period of SKMHT which can then be increased by making APHT at the wishes of the parties.

The provisions of UUHT Number 4 of 1996 provide firmness that the land that will be used as collateral from the object of mortgage to creditors is land rights that have been registered or certified from the local National Land Agency, as well as the provisions in Act No. 10 of 1998 amendments to the Law. -Act No. 7 of 1992 concerning Banking which requires the same as the above. However, considering the very low awareness of some people regarding land that must be registered with the Land Office in order to get a certificate and have definite legal force for the owner.

The use of SKMHT made after or at the same time as the credit agreement occurs because Bank BPR Karya Remaja Regency, Indramayu Regency believes that the loan to be given to the debtor will be safe because of the guarantee provided by the debtor in the form of land ownership rights installed with SKMHT and the results of the Bank's analysis of the ability from the debtor in fulfilling credit installment obligations to repay the credit loan in accordance with the period as agreed upon by the parties.

a. The installation stage of the Power of Attorney for Imposing Mortgage (SKMHT) into a Deed of Granting Mortgage (APHT).

The installation stage of the SKMHT is carried out before a Notary and is carried out after the credit agreement as the main agreement makes agreements between the parties regarding borrowing money by installing Mortgage Rights. The provisions of UUHT Article 15 paragraph (1) letter c state that there is an obligation to include:

1). Name and identity of the holder and grantor of Mortgage.

2). Domicile of the holder and grantor of Mortgage.

3). A clear indication of the debt or debts which are guaranteed to be repaid with Mortgage Rights and includes the name and identity of the debtor concerned.

4). Dependent value.

5). A clear description of the object of Mortgage, which includes details regarding the certificate of land rights in question or for land that has not been registered, at least contains a description of the ownership, location, boundaries, and land area. 
Making SKMHT of a PPAT is subject to the procedure for filling out SKMHT as regulated in letter $h$ (attachment 23) Article 96 paragraph (1) Regulation of the Head of the National Land Agency of the Republic of Indonesia Number 8 of 2012 Amendment to Regulation of the State Minister/To the National Land Agency Number 3 of 1997 Regarding Provisions for Implementation of Government Regulation Number 24 of 1997 concerning Land Registration. As for the Notary himself, must comply with the UUJN, because this UUJN is the main guide for a Notary in making a Notary deed, so that every deed made by a Notary must comply with the rules stipulated in the UUJN so that the deed can be declared as a notarial deed that has the power of proof as an authentic deed.

Article 8 of Act No. 7 of 1992 concerning Banking which in its explanation, among other things, states that: Land whose ownership is based on customary law, namely proof of ownership in the form of girik, petuk, and other similar types can be used as collateral to be accommodated in the UUHT. These lands can be used as collateral by fulfilling the requirements of the UUHT.

The explanation of Article 10 paragraph (3) of the UUHT states, among other things, that the possibility of granting Mortgage Rights on customary land rights is intended to:

a. Provide opportunities for holders of land rights who have not been certified to obtain credit, because there are still many lands with customary property rights.

b. Encouraging the certificate of land rights in general, binding land that has not been certified at this time is still a lot.

The binding of credit guarantees with Mortgage in practice is carried out not based on the provisions of Article $10 \mathrm{UUHT}$, or by making APHT, but the bank in this case only makes a Power of Attorney to Give Mortgage. The binding of credit to the uncertified lands is carried out in the following manner:

1. Making a deed of credit agreement under the hand which can then also be registered in a waarmerking (recorded in a special book by a notary).

2. Making Power of Attorney for Imposing Mortgage Rights (SKMHT).

3. The land owner authorizes the bank to register the land (certificate-making process) and submit all the necessary documents for that purpose.

4. The management of land registration (certificate making process) of the collateral object is carried out through the Notary Office/PPAT appointed by the bank 
Notaries as public officials must be able to follow legal developments so that in providing their services to the community, in helping to overcome and meet growing legal needs, they can provide solutions that are justified by law. Therefore, notaries in carrying out their duties must comply with and be bound by existing regulations, namely the Notary Position Act, the Civil Code, the Notary Code of Ethics and other legal regulations. ${ }^{9}$

Gustav Radbruch interprets legal certainty as positive law, meaning that positive law is legislation. This principle basically expects and requires the law to be made definitively in written form. ${ }^{10}$ Notaries as public officials who carry out the profession in providing legal services to the public receive protection and guarantees of legal certainty as regulated in Act No. 2 of 2014 concerning Amendments to Act No. 30 of 2004 concerning Notary Positions ${ }^{11}$.

In practice, a Notary at Bank BPR Karya Remaja, Indramayu Regency always makes a Power of Attorney for Giving Mortgage Rights (SKMHT) in accordance with Article 15 paragraph (4) of the UUHT, to bind collateral for uncertified lands that will be used as collateral/collateral. SKMHT made by a notary fulfills the requirements regarding its contents as stipulated under Article $15 \mathrm{UUHT}$, among others:

1. SKMHT is made with a Notary deed meeting the following requirements:

a. Does not contain the power to carry out other legal actions than to impose Mortgage Rights; In this provision, for example, it does not contain the power to sell, lease the object of Mortgage or extend land rights.

b. Does not contain substitution power. The definition of substitution here is the replacement of the power of attorney through transfer. Thus, it is not a substitute, if the recipient of the power of attorney gives power to another party in the context of an assignment to act on his behalf, for example, the Board of Directors of the Bank assigns the exercise of the power he has received to the Head of the Branch or other party.

c. Clearly state the object of the Mortgage, the amount of debt and the name and identity of the creditor, the name and identity of the debtor if the

${ }^{9}$ Putri A.R. (2011). Perlindungan Hukum Terhadap Notaris. Medan: Sofmedia. p.5.

${ }^{10}$ Mario Julyano, Aditya Yuli Sulistyawan. (2021). "Pemahaman Terhadap Asas Kepastian Hukum Melalui Konstruksi Penalaran Positivisme Hukum". in Jurnal Crepido. Vol. 01. No. 01. July 2019. Url. https://ejournal2.undip.ac.id/index.php/crepido/article/view/6325. accessed on 1 April 2021.

${ }^{11}$ Deen, Thaufiq., Ong Argo Victoria \& Sumain. (2018). Public Notary Services In Malaysia. JURNAL AKTA: Vol. 5, No. 4, 1017-1026. Retrieved from http://jurnal.unissula.ac.id/index.php/akta/article/view/4135 
debtor is not the provider of the Mortgage. Clarity regarding the main elements in the imposition of Mortgage is very necessary for the protection of the Mortgage giver, while the amount of debt in question is the amount of debt in accordance with the agreement.

2. SKMHT regarding registered land rights followed by making APHT no later than one month after being granted.

3. SKMHT concerning land rights that have not been registered or are still in the registration process must be followed by making APHT no later than three months after the date of issuance of the certificate.

The making of the SKMHT deed by a Notary and the practice of land collateral that has not been certified at Bank BPR Karya Remaja, Indramayu Regency is made by a Notary following the form and format of Article 38 UUJN, although the Land Office has a format in making SKMHT, namely following Perkaban Number 8 of 2012.

The SKMHT made before a Notary at Bank BPR Karya Remaja, Indramyu Regency has also fulfilled what has been determined in Article 38 of the UUJN. In Article 38 UUJN paragraph 1 letters $a$ and $b$ concerning the beginning or the head of the deed and the body of the deed and the head of the deed only contains information or mentions the domicile of the Notary and the names of the parties who come or appear before the Notary and in Article 38 paragraph (2) UUJN head deed contains the title of the deed, deed number, hour, day, date, month, year, and the full name and domicile of the Notary.

\subsection{Obstacle factor}

The implementation of making SKMHT which starts from the stage before the credit agreement which is followed up by signing credit and making SKMHT in its implementation in the field of course not everything goes smoothly, sometimes there are some obstacles and obstacles faced by Notaries. These obstacles can come from the Bank, the debtor, or others.

a. Inhibiting factor from the Bank.

The incomplete document is an obstacle in making SKMHT which is then upgraded to APHT which will be sent for registration to the Land Agency. It takes time to collect supporting documents, because the registration of Mortgage Rights to the Land office is not only the deed that is entered but also must attach other supporting documents, especially during the Covid-19 pandemic like this. 
b. Inhibiting factor on the part of the debtor.

The problem of the amount of fees is an inhibiting factor for debtors when upgrading SKMHT to APHT where the certification process for objects that are guaranteed from SKMHT that have not been registered and if the conversion process, splitting, merging certificates, inheritance, buying and selling, grants is carried out, is a number of the process that must be passed first before the guarantee for the land is charged as a Mortgage to the Land Agency Office. If a debtor wants to apply for credit to a bank with a guarantee of immovable property in the form of land in large quantities, Mortgage rights must automatically be installed and the debtor is subject to Non-Tax State Revenue which is abbreviated as PNBP which must be paid to the state.

c. Bad credit

Credit congestion caused by changes in economic conditions, of course the debtor is reluctant to provide a new SKMHT if the old SKMHT has expired, because if the debtor is naughty, it can evade its responsibility to repay its debt or try to buy time.

\subsection{Solution}

There are factors that become obstacles in the implementation of making SKMHT, the Notary takes steps and solutions to overcome obstacles that occur in the field including the following:

a. Efforts to Overcome Inhibiting Factors from Creditors (Banks).

To overcome the factors that hinder the completeness of documents from the Bank, the Notary solves the problem by providing understanding, direction and active communication to bank employees, especially in the marketing and legal department which handles the document equipment section of the debtor regarding the provision of a period of time for registration of Mortgage Rights issued by the debtor restricted from the Land Office. To the bank to prepare the supporting documents required in the attachment of the Mortgage registration sheet. The same applies to SKMHT and APHT, which must be signed by the head of the bank for the purposes of registering Mortgage Rights at the local Land Office. For this reason, the notary will give 7 working days to complete the complete documents from the Bank. As in the case of the Identity Card which has expired. So the efforts made by the Notary are by contacting the Bank so that the customer can provide the latest ID or identity card.

b. Efforts to Overcome Inhibiting Factors from the Debtor 
Inhibiting factors from the debtor include the amount of costs in making SKMHT and APHT charged to the debtor, for example related to the issue of Non-Tax State Revenue (PNBP) which is considered quite burdensome in the installation of Mortgage Rights. Efforts to overcome the problem of costs which are an obstacle for making the Mortgage Deed until the issuance of a mortgage certificate which is considered too expensive for some debtors, the bank gives the freedom to negotiate with the Notary either through the bank which is then forwarded to the Notary to ask for fee waivers or the customer directly meet the Notary and negotiate the cost of making APHT.

c). Regarding the problem of bad loans, creditors should try to be more careful in providing credit, because SKMHT is an authorized institution and not as a guarantee institution in repaying a loan. In this case, there is a risk of loss for the bank if the debtor suddenly goes bankrupt or breaks his contract.

\section{Closing}

The conclusion of this research is that the role of the Notary in making the deed of Power of Attorney for Imposing Mortgage Rights (SKMHT) on land collateral that has not been certified at Bank BPR Karya Remaja, Indramayu Regency in practice, the Notary makes SKMHT in accordance with Article 15 UUHT to bind collateral for lands that have not certificate which will be used as collateral, and has fulfilled what has been determined in Article 38 of the UUJN regarding the beginning of the deed, the body of the deed, and the closing of the deed. In general, the implementation of making SKMHT by a Notary at Bank BPR Karya Remaja, Indramayu Regency is after a credit agreement. SKMHT as a form of guarantee for repayment of debt from debtors to creditors as financiers. The obstacles faced by the Notary in making the SKMHT deed for land collateral that has not been certified at Bank BPR Karya Remaja, Indramayu Regency are a). The inhibiting factor from the Bank, namely the incomplete document, b). The Inhibiting Factor from the Debtor is the problem of the amount of fees. c). Bad credit. The solutions to overcome these obstacles are: a). Give 7 working days to complete documents from the Bank or customer. b). Negotiated costs with a Notary, c). Banks are careful in providing credit.

\section{References}

Journals:

[1] Deen, Thaufiq., Ong Argo Victoria \& Sumain. (2018). Public Notary Services In Malaysia. JURNAL AKTA: Vol. 5, No. 4, 1017-1026. Retrieved from http://jurnal.unissula.ac.id/index.php/akta/article/view/4135 
[2] Dimas Agung Prastomo, Akhmad Khisni,. (2017). "Akibat Hukum Akta Di Bawah Tangan Yang Dilegalisasi Oleh Notaris". In Jurnal Akta, vol. 4. No.4. Desember 2017.

Url. http://jurnal.unissula.ac.id/index.php/akta/article/view/2519. accessed on 3 March 2021.

[3] Mario Julyano, Aditya Yuli Sulistyawan. (2021). "Pemahaman Terhadap Asas Kepastian Hukum Melalui Konstruksi Penalaran Positivisme Hukum". In Jurnal Crepido. Vol. 01. No. 01. July 2019. Url. https://ejournal2.undip.ac.id/index.php/crepido/article/view/6325. accessed on 1 April 2021.

[4] Sayuna, Inche. (2014). "Problematika Surat Kuasa Membebankan Hak Tanggungan (SKMHT) Dari Dimensi: Subjek, Objek dan Kepentingan Yuridis". in Jurnal Reportorium Volume 1. Nomor 1. January-June 2014, Url. https://www.neliti.com/publications/212960/problematika-suratkuasa-membebankan-hak-tanggungan-skmht-dari-dimensi-subjek-ob. Accessed on 15 March 2021.

Books:

[1] Adjie, Habib. (2019). Hukum Notaris Indonesia (Tafsir Tematik Tehadap UU No.30 Tahun 2004 tentang Jabatan Notaris). Bandung: Refika Aditama. hal. 16.

[2] Handoko, Widhi. (2019). Dominasi Negara Terhadap Profesi Notaris Antara Ide dan Realitas. Bogor: Roda Publikasi Kreasi.

[3] Putri A.R. (2011). Perlindungan Hukum Terhadap Notaris. Medan: Sofmedia

[4] Sjaifurrachman. (2011). Aspek Pertanggungjawaban Notaris dalam Pembuatan Akta. Bandung: Mandar Maju.

[5] Supramono, Gatot. (2013). Perjanjian Utang Piutang. Jakarta: Kencana.

[6] Syamsudin, M. (2007). Operasionalisasi Penelitian Hukum. Jakarta: PT Raja Grafindo Persada. 